\title{
Relation between LDH and Mg as Factors of Interest in the Monitoring and Prognoses of Cancer
}

\author{
Aurelian Udristioiu ${ }^{1 *}$, Sorina Comisel$^{2}$, Cristina Popescu ${ }^{3}$ and Manole Cojocaru ${ }^{4}$ \\ ${ }^{1}$ Emergency County Hospital Targu Jiu Romania, Clinical Laboratory Medical Analyses, Progresului Street No: 18, City Targu Jiu, Romania \\ ${ }^{2}$ UMF Craiova, Medicine Faculty, Endocrinology, Craiova, Romania \\ ${ }^{3}$ Medistar S.R.L Targu-Jiu, Biochemist Departement, Romania \\ ${ }^{4}$ Titu Maiorescu University, Medicine Faculty, Physiology, Romania
}

\begin{abstract}
The aim of this work was to evaluate the correlation between the serum levels of lactate dehydrogenase (LDH) and magnesium $(\mathrm{Mg})$ alone or in report $\mathrm{Ca} / \mathrm{Mg}$, among patients with diagnosed malignant diseases who were admitted to the oncology department of a county hospital.

Results: Among the patients in this study, 55 patients (73\%) exhibited normal serum levels of $\mathrm{Mg}$ (normal range value $=1.60-2.3 \mathrm{mg} / \mathrm{dL} ;$ mean value $=2.2 \mathrm{mg} / \mathrm{dL} ; \mathrm{SD}=0.2 ; \mathrm{p}=0.02$ ), normal values for $\mathrm{Ca}$ (range $9.1-10.8 \mathrm{mg} / 100$ $\mathrm{m}$, mean value $=9.90, \mathrm{SD}=2.5, \mathrm{P}=0.05)$ and normal report $\mathrm{Ca} / \mathrm{Mg}$ (range 4.5-7), following cancer therapy with good results, in the stage of remission tumor.

A number of 12 patients (16\%), which was discovered in onset of cancer diseases, displayed high levels of serum $\mathrm{Mg}$ (range =2.6-3.27 mg/dL; mean value $=2.89 \mathrm{mg} / \mathrm{dL}$ ), high values of $\mathrm{Ca}$, (mean value $=11.2 \mathrm{mg} / \mathrm{dl}$ ), and low values of report $\mathrm{Ca} / \mathrm{Mg}$ ( range $=1.7-3.8$ ).

Six patients (8\%), with bad prognostic, unfavorable cancer therapy and frequent relapses, exhibited low levels of $\mathrm{Mg}$ (range $=0.60-1.50 \mathrm{mg} / \mathrm{dl}$; mean value $=1.05 \mathrm{mg} / \mathrm{dL}$ ), low values of $\mathrm{Ca}(8.2-8.8 \mathrm{mg} / \mathrm{dl}$ ) but high report Ca/Mg (range $=8.3-23.5$ ). High $\mathrm{Ca} / \mathrm{Mg}$ ratio was also significantly associated with high-grade cancer.

The levels of serum lactic dehydrogenase (LDH) were also evaluated in patients newly diagnosed with cancer and in patients with unfavorable responses to the cancer therapy (range $=240-1330 \mathrm{U} / \mathrm{L} ;$ mean value $=787 \mathrm{U} / \mathrm{L} ; \mathrm{SD}$ $=1.33 ; p=0.002 ;$ normal values $135-225 \mathrm{U} / \mathrm{L}$ ).
\end{abstract}

Conclusion: The total serum LDH, Mg and report Ca/Mg levels can be used as markers for the onset of malignant diseases and for monitoring the response to cancer therapy.

\begin{abstract}
Abbreviations: LDH- Lactate dehydrogenase; IDH- Isocitrate dehydrogenase; CLL- Chronic lymphocytic leukemia; LAM-3- Acute promyelocytic leukemia; TRPM6- Transient receptor potential melastatin cation channel 6; NADH- Nicotinamide dehydrogenase
\end{abstract}

\section{Introduction}

Magnesium, which is the second most abundant intracellular cation after potassium, has an essential role in the regulation of numerous cellular functions and enzymes, including ion channels, metabolic cycles and signaling pathways.

Approximately $60 \%$ of magnesium ions $(1215 \mathrm{mg} / \mathrm{dL})$ are stored in tissues and approximately $40 \%$ of magnesium ions $(972 \mathrm{mg} /$ $\mathrm{dL})$ contribute to intermediary metabolism. Among these ions, approximately $70 \%(680 \mathrm{mg})$ exist in the free form, $\mathrm{Mg}^{2+}$, whereas the other $30 \%$ of ions $(292 \mathrm{mg} / \mathrm{dL}$ ) are bound to proteins (especially albumin), citrate, phosphate and other complexes. The magnesium serum levels are kept constant within very narrow limits (0.65$1.05 \mathrm{mmol} / \mathrm{dL} ; 1.58-2.25 \mathrm{mg} / \mathrm{dL}$ ). Regulation occurs in the kidneys, especially via the ascending loop of Henle $[1,2,3]$.

The magnesium ion $\left(\mathrm{Mg}^{2+}\right)$ is critical for maintaining the positional integrity of closely clustered phosphate groups. These clusters appear in numerous distinct parts of the cell nucleus and cytoplasm. The $\mathrm{Mg}^{2+}$ maintains the integrity of nucleic acids, ribosomes and proteins. In addition, this ion acts as an oligo-element with role in energy catalysis [4].

Biological cell membranes and cell walls exhibit poly-anionic charges on the surface. This finding has important implications for the transport of ions, particularly because different membranes preferentially bind different ions. Both $\mathrm{Mg}^{2+}$ and $\mathrm{Ca}^{2+}$ regularly stabilize membranes by cross-linking the carboxylated and phosphorylated head groups of lipids.

Biological membranes are impermeable to $\mathrm{Mg}^{2+}$ (and other ions). Therefore, transporter proteins must facilitate the flow of $\mathrm{Mg}^{2+}$ into and out of cells or intracellular compartments. The reasons for the major fluxes of $\mathrm{Mg}^{2+}$ in either direction across the plasma membrane of mammalian cells following metabolic stimulus and how these mechanisms are altered under specific pathological conditions are currently unknown. The current molecular sub-study was independently funded to test the priori hypothesis that low serum magnesium levels are associated with increased risk of prostate cancer, perhaps more so among men with elevated calcium levels [5].

*Corresponding author: Aurelian Udristioiu, Emergency County Hospital, Targu Jiu Romania, Clinical Laboratory Medical Analyses, Progresului street No: 18, City Targu Jiu, Romania, Phone/Fax: 40253210432; E-mail: aurelianu2007@yahoo.com

Received December 10, 2011; Accepted December 27, 2011; Published January 30, 2012

Citation: Udristioiu A, Comisel S, Popescu C, Cojocaru M (2012) Relation between $\mathrm{LDH}$ and $\mathrm{Mg}$ as Factors of Interest in the Monitoring and Prognoses of Cancer. Bioanal Biomed 4: 001-005. doi:10.4172/1948-593X.1000055

Copyright: @ 2012 Udristioiu A, et al. This is an open-access article distributed under the terms of the Creative Commons Attribution License, which permits unrestricted use, distribution, and reproduction in any medium, provided the original author and source are credited. 
In last few years, research studies made associations between serum magnesium and calcium/magnesium ratio and risk of prostate cancer, whereas all other analyses were conducted to support the primary analysis or to explore nature of primary findings. Furthermore, prior studies in humans found lower levels of magnesium (thus, higher serum calcium/magnesium ratio) leading to inflammation and insulin resistance which have been linked to progression of prostate cancer [6].

Two recent studies found higher serum calcium levels associated with aggressive lesions or fatal cancer [7]. The lower ratio of calcium to magnesium was also associated with high-grade prostate cancer, suggesting the interaction between magnesium and calcium plays a role in the pathogenesis and progression of this disease to a more clinically relevant phase. Calcium levels alone, in contrast, were not consistently associated with prostate cancer [8].

The research suggested that increased blood magnesium levels have an effect that may be at least partially dependent on calcium levels toward the pathogenesis for high-grade prostate cancer [9]. Given the broad range of biological functions dependent on magnesium, it is highly plausible that magnesium deficiency may affect multiple pathways toward tumorigenesis across the body. For example, a recent study found mice transplanted with Lewis Lung Carcinoma and receiving a low- $\mathrm{Mg}$ diet had a significant $70 \%$ reduction in primary tumor growth, but also had a higher metastatic potential [10].

Malignant cells use $\mathrm{Mg}^{2+}$ ions in metabolism more frequently than normal cells do and promote the uptake of magnesium from stores in normal tissues, including bones and muscles [11]. The proliferation of osteoclast cells occurs when the intracellular $\mathrm{Ca} / \mathrm{Mg}$ ratio is $3 / 2$. $\mathrm{Mg}^{2+}$ generally interacts with substrates via the inner coordination sphere, stabilizing anions or reactive intermediates, binding ATP and activating molecules for nucleophillic attack [12].

In cells, the immediate energy sources involve glucose oxidation. In anaerobic metabolism, the donor of the phosphate group is adenosine triphosphate (ATP) and the reaction is catalyzed via the hexokinase or glucokinase: Glucose +ATP- $\mathrm{Mg}^{2+}=$ Glucose-6-phosphate $(\Delta \mathrm{Go}=-3.4$ $\mathrm{kcal} / \mathrm{mol}$ with hexokinase as the co-enzyme for the reaction).

In the following step, the conversion of G-6-phosphate into F-16-bisphosphate is mediated by the enzyme phosphofructokinase with the co-factor ATP- $\mathrm{Mg}^{2+}$. This reaction has a large negative free energy difference and is irreversible under normal cellular conditions. In the second step of glycolysis, phosphoenolpyruvic acid in the presence of $\mathrm{Mg}^{2+}$ and $\mathrm{K}^{+}$is transformed into pyruvic acid. In cancer cells or in the absence of oxygen, the transformation of pyruvic acid into lactic acid alters the process of glycolysis.

The energetic sum of anaerobic glycolysis is $\Delta \mathrm{Go}=-34.64 \mathrm{kcal} / \mathrm{mol}$. However a glucose molecule contains $686 \mathrm{kcal} / \mathrm{mol}$ and, the energy difference $(654.51 \mathrm{kcal})$ allows the potential for un-controlled reactions during carcinogenesis. The transfer of electrons from NADPH in each place of the conserved unit of energy transmits conformational exchanges in the mitochondrial ATPase. The reaction $\mathrm{ADP}^{3}+\mathrm{P}^{2-}+\mathrm{H}^{2}-$ $\rightarrow$ ATP $+\mathrm{H}_{2} \mathrm{O}$ is reversible. The terminal oxygen from ADP binds the $\mathrm{P}^{2-}$ by forming an intermediate pentacovalent complex, resulting in the formation of ATP and $\mathrm{H}_{2} \mathrm{O}$. This reaction requires $\mathrm{Mg}^{2+}$ and an ATPsynthetase, which is known as the H+-ATPase or the Fo-F1-ATPase complex. Intracellular calcium induces mitochondrial swelling and aging.

The known marker of monitoring of treatment in cancer diseases, lactate dehydrogenase (LDH) is an enzyme that is localized to the cytosol of human cells and catalyzes the reversible reduction of pyruvate to lactate via using hydrogenated nicotinamide deaminase (NADH) as co-enzyme [13].

The causes of high LDH and high Mg levels in the serum include neoplastic states that promote the high production of intracellular $\mathrm{LDH}$ and the increased use of $\mathrm{Mg}^{2+}$ during molecular synthesis in processes of carcinogenesis (Pyruvate acid $>$ LDH/NADH $>>$ Lactate acid + NAD)

LDH is released from tissues in patients with physiological or pathological conditions and is present in the serum as a tetramer that is composed of the two monomers LDH-A and LDH-B, which can be combined into 5 isoenzymes: LDH-1 (B4), LDH-2 (B3-A1), LDH-3 (B2-A2), LDH-4 (B1-A3) and LDH-5 (A4). The LDH-A gene is located on chromosome 11 , whereas the $\mathrm{LDH}-\mathrm{B}$ gene is located on chromosome 12 . The monomers differ based on their sensitivity to allosteric modulators. They facilitate adaptive metabolism in various tissues. The LDH-4 isoform predominates in the myocardium, is inhibited by pyruvate and is guided by the anaerobic conversion to lactate.

Total $\mathrm{LDH}$, which is derived from hemolytic processes, is used as a marker for monitoring the response to chemotherapy in patients with advanced neoplasm with or without metastasis. LDH levels in patients with malignant disease are increased as the result of high levels of the isoenzyme LDH-3 in patients with hematological malignant diseases and of the high level of the isoenzymes LDH-4 and LDH-5, which are increased in patients with other malignant diseases of tissues such as the liver, muscle, lungs and conjunctive tissues. High concentrations of serum LDH damage the cell membrane [14].

Aim of this work was to evaluate the correlation between the serum levels of lactate dehydrogenase $(\mathrm{LDH})$ and magnesium $(\mathrm{Mg})$ alone or in report $\mathrm{Ca} / \mathrm{Mg}$, among patients with diagnosed malignant diseases who were admitted to the oncology department of a county hospital.

\section{Methods}

We analyzed a cohort of patients $(\mathrm{n}=75)$ comprising males $(\mathrm{n}=$ $36)$ and females $(\mathrm{n}=39)$ with a mean age of 57 years $(\mathrm{SD}=12.5)$ who had cancer diseases treated in oncology department. These patients were closely monitored twice weekly during treatment with specific cytostatic drugs of induction (using fluorouracil, leucovorin, oxaliplatin or rituximab) and once weekly during consolidation therapy, using specific analyses for different cancer form.

By the cooperation with doctors and in according with patients, we performed hematological and biochemical tests, $\mathrm{CBC}$ with differential counts, the levels of creatinine, uric acid, ions and electrolytes (potassium, chloride, calcium with calculated report: $\mathrm{Ca} / \mathrm{Mg}$ ), serum $\mathrm{LDH}$ and $\mathrm{Mg}$, which may be serve as markers for monitoring and progression of malignant diseases.

The hematological parameters were assessed using a Beckman Coulter HMX analyzer, USA, with a total of 22 parameters and microscopic slides. The biochemical parameters were measured using a Vitros 250 dry chemistry analyzer (Johnson \& Johnson, USA) using the slides for multi-layer spectrophotometry measurements.

We excluded patients with non-neoplastic pathologies or diseases that can induce increased serum levels of $\mathrm{Mg}$ and $\mathrm{LDH}$. The excluded diseases included acute or chronic renal failure (CRF), ischemic heart disease, lung infarction, liver cirrhosis, acute or chronic hepatitis, massive muscle injury, megaloblastic anemia and severe syndromes that are associated with respiratory failure. 
The physicians from the county hospital had prescribed to patients only the cancer therapy recommended by the Oncology Institute Fundeni, from Bucharest. Among the patients, 8 patients were diagnosed with lung cancer, 18 patients were diagnosed with breast cancer, 19 patients were diagnosed with genital cancer, 23 patients were diagnosed with colorectal cancer, 5 patients were diagnosed with chronic lymphocytic leukemia (CLL), 1 patient was diagnosed with acute promyelocytic leukemia (LAM-3) and 1 patient was diagnosed with chronic monocytic leukemia (CMoL).

The complete blood count, blood biochemistry assays, chest and whole body radiography, echocardiography and thoracic ultrasound and/or abdominal computed tomography (CT) scans were performed for each patient to establish the type of cancer.

The May-Grunwald-Giemsa method was used to determine the microscopic appearance of peripheral blood lymphocytes from patients with incipient leukemia who had not received prior treatment or a hematopoietic stem cell transplant (HSCT). Morphologically, in B-cell CLL, the cells resembled normal clonal B cells that had arrested during $B$ cell differentiation between the pre- $B$ cell and mature $B$ cell stages. An initial panel of monoclonal antibodies was used to determine the immune phenotypes of the subgroups of differentiated $\mathrm{T}$ cells and $\mathrm{B}$ cells.

Activated B lymphocytes in CLL patients were defined as CD5+/ CD19+ cells that expressed CD23 and/or CD38 as surface markers. Activated T cells in patients with T-cell CLL were identified using CD7, CD5, CD3, CD2, CD4, CD8 and CD45 RO.

The sample stability was maximal at one hour at $15-25^{\circ} \mathrm{C}$, in conformity with the conditions of the delivery of samples for the primary sample collection, following the instructions of the manufacturer and respecting the Procedures of Collection of Diagnostic Blood Specimens by Venipuncture, NCCLS Document H4-A3 Wayne, PA: NCCLS; 1991. We excluded samples from the study based on the following criteria: an icteric index $>65$ for conjugated bilirubin and an icteric index $>37$ for un-conjugated bilirubin, hemolysis with an $\mathrm{H}$ index $>$ 400 , turbidity for triglycerides $>300 \mathrm{mg} / \mathrm{dl}$ and serum containing paraproteins (multiple myeloma).

The diagnosis of LAM-3 was made based on blood smears, the examination of bone marrow (BM) aspirates, the evaluation of promyeloblasts (greater than $30 \%$ in $\mathrm{BM}$ ) and the presence of a specific immune phenotype. Immunocytochemical detection was performed to confirm the diagnosis of LAM-3 using FAR Leukemia kits (Italy) and there were positive results for the peroxidase reaction for promyelocytes, myelocytes, granulocytes and peripheral blood cells $(\mathrm{POX}+)$ and negative results for the peroxidase reaction for the blast cells. We performed the leukocyte alkaline phosphatase reaction using a SIGMA kit (www.sigmaaldrich.com) to determine the neutrophil alkaline phosphatase (NAP) levels in granulocytes (negative or low values in LAM-3) and to evaluate the alpha-naphthyl-esterase reaction in monocytes cells (positive results indicate $\mathrm{CMoL}$ ).

\section{Results}

The results were interpreted for each patient based on medical history, clinical and para-clinical examinations and other signs of malignant diseases. Among the patients in this study, 55 patients (73\%) exhibited normal serum levels of $\mathrm{Mg}$ (normal range value $=1.60-2.3$ $\mathrm{mg} / \mathrm{dL} ;$ mean value $=2.2 \mathrm{mg} / \mathrm{dL} ; \mathrm{SD}=0.2 ; \mathrm{p}=0.02$ ), normal values for $\mathrm{Ca}$ (range $9.1-10.8 \mathrm{mg} / 100 \mathrm{~m}$, mean value $=9.90, \mathrm{SD}=2.5, \mathrm{P}=0.05$ ) and normal report $\mathrm{Ca} / \mathrm{Mg}$ (range 4.5-7), following cancer therapy with good results, in the stage of remission tumor.

A number of 12 patients (16\%), which was discovered in onset of cancer diseases, displayed high levels of serum $\mathrm{Mg}$ (range $=2.6-3.27$ $\mathrm{mg} / \mathrm{dL}$; mean value $=2.89 \mathrm{mg} / \mathrm{dL})$, high values of $\mathrm{Ca}$, $($ mean value $=$ $11.2 \mathrm{mg} / \mathrm{dl})$, and low values of report $\mathrm{Ca} / \mathrm{Mg}($ range $=1.7-3.8)$.

Six patients (8\%), with bad prognostic, unfavorable cancer therapy and frequent relapses, exhibited low levels of $\mathrm{Mg}$ (range $=0.60-1.50$ $\mathrm{mg} / \mathrm{dl}$; mean value $=1.05 \mathrm{mg} / \mathrm{dL})$, low values of $\mathrm{Ca}(8.2-8.8 \mathrm{mg} / \mathrm{dl})$ but high report $\mathrm{Ca} / \mathrm{Mg}$ (range $=8.3-23.5)$.

The levels of serum lactic dehydrogenase (LDH) were also evaluated in patients newly diagnosed with cancer and in patients with unfavorable responses to the cancer therapy (range $=240-1330 \mathrm{U} / \mathrm{L}$; mean value $=787 \mathrm{U} / \mathrm{L} ; \mathrm{SD}=1.33 ; \mathrm{p}=0.002 ;$ normal values $135-225$ $\mathrm{U} / \mathrm{L})$ (Table 1).

\section{Discussion}

In this study was observed that in malignant diseases the serum $\mathrm{Mg}$ values are high, normal or low independent of the serum $\mathrm{LDH}$ values, which are increased during the onset of malignant diseases. $\mathrm{LDH}$ levels remain elevated following the initial cytostatic treatment until cancer remission. The serum $\mathrm{Mg}$ level is increased via $\mathrm{Mg}^{2+}$ release from malignant tissues in patients with malignant disease prior to treatment with cytostatic drugs. We consider that $\mathrm{Mg}$ is a good marker if it's high in newly diagnosed patients (first column of table 1) but low in patients with unfavorable response to therapy (third column of table 1). Variations of $\mathrm{Mg}$ levels in cancer diseases can be a cause of progression or remissions of malignant disease in time of initial and current therapy.

The lower ratio of calcium to magnesium was also associated with high-grade cancer, suggesting the interaction between magnesium and calcium plays a role in the pathogenesis and progression of this disease to a more clinically relevant phase. High $\mathrm{Ca} / \mathrm{Mg}$ ratio was also significantly associated with high-grade cancer.

In specialty lectures were explained, more theoretically the processes of carcinogenesis with implication of LDH and magnesium from all cellular and intracellular levels. These results, obtained in our study, we can interpret in light of other reports on the connection of $\mathrm{Mg}$ and LDH with cancer.

A magnesium ion progressively removes nearly all of the water via a selective pore before the magnesium ion is released on the far side of the membrane [14]. These changes occur with low rates of ligand exchange in an inner coordination complex comprising water and $\mathrm{Mg}^{2+}$ [15]. The transport mechanisms depend on the 3-D structure of the complex that is formed via the hydration of the $\mathrm{Mg}^{2+}$ ion in an aqueous environment. The inner shell of this complex comprises 6 water molecules that are relatively tightly bound and the second shell comprises 12-14 water molecules. The pore is a funnel-shaped homopentamer with two transmembrane helices per monomer composed of carbohydrate and lipid chains. The channel is formed by an inner group of 5 helices and is gated by bulky hydrophobic residues. The cytoplasmic neck of the pore is surrounded by a ring of highly conserved positively charged residues on the outside of the funnel [16].

The transient receptor potential melastatin cation channel 6 (TRPM6) forms a $\mathrm{Mg}^{2+}$ permeable pore. TRPM6 has an active cytosolic kinase domain and is considered a master regulator of cellular $\mathrm{Mg}^{2+}$ homeostasis. Another transient receptor potential melastatin cation channel, TRPM7, is an important cytosolic protein kinase that is 
Citation: Udristioiu A, Comisel S, Popescu C, Cojocaru M (2012) Relation between LDH and Mg as Factors of Interest in the Monitoring and Prognoses of Cancer. J Bioanal Biomed 4: 001-005. doi:10.4172/1948-593X.1000055

\begin{tabular}{|c|c|c|c|}
\hline Number of cases & $\begin{array}{l}\text { Serum LDH and Mg levels to patients in onset of } \\
\text { malignant diseases }\end{array}$ & $\begin{array}{l}\text { Serum LDH and Mg levels to patients in the } \\
\text { remission stage }\end{array}$ & $\begin{array}{l}\text { Serum } \mathrm{LDH} \text { and } \mathrm{Mg} \text { levels to } \\
\text { patients with relapse }\end{array}$ \\
\hline Patients $=8$ & $\begin{array}{l}\text { Lung Cancer } \\
\text { Mean value: } \\
\mathrm{LDH}=1270 \\
\mathrm{Mg}=2.85 \\
\mathrm{Ca}=11.4\end{array}$ & $\begin{array}{l}\text { Lung Cancer } \\
\text { Mean value: } \\
\mathrm{LDH}=254 \\
\mathrm{Mg}=1.60 \\
\mathrm{Ca}=9.5\end{array}$ & $\begin{array}{l}\text { Lung } \\
\text { Cancer } \\
\text { Mean value: } \\
\mathrm{LDH}=1330 \\
\mathrm{Mg}=1.06 \\
\mathrm{Ca}=8.8\end{array}$ \\
\hline Patients $=18$ & $\begin{array}{l}\text { Breast Cancer } \\
\text { Mean value: } \\
\mathrm{LDH}=1250 \\
\mathrm{Mg}=2.55\end{array}$ & $\begin{array}{l}\text { Breast } \\
\text { Cancer } \\
\text { Mean value: } \\
\mathrm{LDH}=250 \\
\mathrm{Mg}=1.80 \\
\mathrm{Ca}=9.2\end{array}$ & $\begin{array}{l}\text { Breast } \\
\text { Cancer } \\
\text { Mean value: } \\
\mathrm{LDH}=1260 \\
\mathrm{Mg}=0.87 \\
\mathrm{Ca}=8.6\end{array}$ \\
\hline Patients $=19$ & $\begin{array}{l}\text { Genital Cancer } \\
\text { Mean value: } \\
\mathrm{LDH}=1245 \\
\mathrm{Mg}=2.72 \\
\mathrm{Ca}=11.8\end{array}$ & $\begin{array}{l}\text { Genital } \\
\text { Cancer } \\
\text { Mean value: } \\
\mathrm{LDH}=260 \\
\mathrm{Mg}=1.88 \\
\mathrm{Ca}=9.4\end{array}$ & $\begin{array}{l}\text { Genital } \\
\text { Cancer } \\
\text { Mean value: } \\
\mathrm{LDH}=1260 \\
\mathrm{Mg}=0.36 \\
\mathrm{Ca}=8.5\end{array}$ \\
\hline Patients $=23$ & $\begin{array}{l}\text { Colorectal } \\
\text { Cancer } \\
\text { Mean value: } \\
\mathrm{LDH}=1250 \\
\mathrm{Mg}=2.70 \\
\mathrm{Ca}=11.6\end{array}$ & $\begin{array}{l}\text { Colorectal } \\
\text { Cancer } \\
\text { Mean value: } \\
\mathrm{LDH}=250 \\
\mathrm{Mg}=1.7 \\
\mathrm{Ca}=10.2\end{array}$ & $\begin{array}{l}\text { Colorectal } \\
\text { Cancer } \\
\text { Mean value: } \\
\mathrm{LDH}=1260 \\
\mathrm{Mg}=0.63 \\
\mathrm{Ca}=8.9\end{array}$ \\
\hline Patients $=7$ & $\begin{array}{l}\text { Acute and Chronic Leukemia } \\
\text { Mean value: } \\
\mathrm{LDH}=1290 \\
\mathrm{Mg}=3.75 \\
\mathrm{Ca}=12,2\end{array}$ & $\begin{array}{l}\text { Acute and Chronic Leukemia } \\
\text { Mean value: } \\
\mathrm{LDH}=255 \\
\mathrm{Mg}=2.05 \\
\mathrm{Ca}=10.6\end{array}$ & $\begin{array}{l}\text { Acute and Chronic Leukemia } \\
\text { Mean value: } \\
\text { LDH }=1330 \\
\mathrm{Mg}=0.6 \\
\mathrm{Ca}=8.4\end{array}$ \\
\hline
\end{tabular}

Table 1: Serum LDH and Mg levels of patients with malignant diseases. (Normal value in healthy patients: LDH = 135-225 U/L; Mg =1.6-2.3 mg/dl; Ca =9.1 -10.8mgdl).

implicated in magnesium transport across the cell membrane and plays a crucial role in proliferating stem cells. The genetic deletion of TRPM7 in $\mathrm{B}$ cells results in $\mathrm{Mg}^{2+}$ deficiency and severe growth impairment, which can be rescued by supplementation with excess extra-cellular $\mathrm{Mg}$. The mRNA expression of the selective $\mathrm{Mg}^{2+}$ transporter MagT1 is up-regulated in TRPM7 (-/-) cells. Furthermore, the over-expression of MagT1 in TRPM7 (-/-) cells augments Mg (+) uptake and improves growth behavior in the absence of excess $\mathrm{Mg}$ [17-22].

The divalent mineral cations $\mathrm{Ca}^{2+}$ and $\mathrm{Mg}^{2+}$ play many and diverse roles both in the function of cells and in extracellular processes. The metabolism of these cations is a complex process involving the coordinated function of several organ systems and endocrine glands. A recently cloned G-protein-coupled receptor responds to extracellular calcium concentration ( $\mathrm{Ca} 2+0$-sensing receptor, $\mathrm{CaSR})$ and mediates several of the known effects of $\mathrm{Ca} 2+0$ on parathyroid and renal function. The CaSR, which is also expressed in a number of other tissues including thyroidal C-cells, brain and gastrointestinal tract, may function as a $\mathrm{Ca} 2+0$ sensor in these tissues as well [34].

In aerobic glucose metabolism, the oxidation of citric acid requires $\mathrm{ADP}$ and $\mathrm{Mg}^{2+}$, which will increase the speed of the reaction: Iso-citric acid + NADP (NAD) --- isocitrate dehydrogenase (IDH) = alphaketoglutaric acid. In the Krebs cycle (the citric cycle), IDH1 and IDH2 are $\mathrm{NADP}^{+}$-dependent enzymes that normally catalyze the interconversion of D-isocitrate and alpha-ketoglutarate ( $\alpha-\mathrm{KG})$. The IDH1 and IDH2 genes are mutated in $>75 \%$ of different malignant diseases. Two distinct alterations are caused by tumor-derived mutations in IDH1 or IDH2: the loss of normal catalytic activity in the production of $\alpha$-ketoglutarate $(\alpha-K G)$ and the gain of catalytic activity to produce 2-hydroxyglutarate (2-HG) [23].

This product is a competitive inhibitor of multiple $\alpha$-KG-dependent dioxygenases, including demethylases, prolyl-4-hydroxylase and the TET enzymes family (Ten-Eleven Translocation-2), resulting in genome-wide alternations in histones and DNA methylation $[2,24]$.

IDH1 and IDH2 mutations have been observed in myeloid malignancies, including de novo and secondary AML (15\%-30\%) and in pre-leukemic clone malignancies, including myelodysplastic syndrome and myeloproliferative neoplasm (85\% of the chronic phase and $20 \%$ of transformed cases in acute leukemia) [25].

The energy of oscillation for the hydrogen atom in water is $0.04^{\star} 10$ ${ }^{5} \mathrm{mV}$. The difference between the excited state $\left(J=\mathrm{E}^{1}\right)$ and the ground state $\left(\mathrm{J}=\mathrm{E}^{\circ}\right)$ for the hydrogen atom is $1 \times 0.059 \mathrm{mV}$. The energy supply $\left(\mathrm{E}^{\circ}+0.059 \mathrm{mV}\right)$ from a magnesium ion, which transfers the activation energy of $\mathrm{Mg}$ to the electron in water, increases the $\mathrm{pH}$ in the system. The excited state of trans-conformation indicates that the angle of the $\mathrm{O}-\mathrm{H}$ increases from the ground-state angle of 105 degrees to 108 degrees [26].

At room temperature, water molecules in a liquid such as the blood in the heart pulse and move in the same plane (twisting) or in and out of the plane (rocking). The main changes in the inter-atomic distance are between the atoms of the bridge fragment $\mathrm{O}-\mathrm{H}$. During excitation, the total length of distance between the $\mathrm{H}$ and $\mathrm{O}$ atoms is increased by $0.3 \mathrm{~A}$. The van der Waals forces create a distance of 2-3 A and depend on the steric energy $\left(0.04^{\star} 10^{-3} \mathrm{mV}\right)$ [27].

The energy of isomerization is accounted for by the P-Po status. Because of the electron redistribution from the central oxygen ion in the water molecule $\mathrm{H}-\mathrm{O}-\mathrm{H}$, the $\mathrm{O} 1 / 2$ ion binds two ions of $\mathrm{H}^{+}$to generate more energy and remains in this state for an extended period as a biological memory. The energy of distilled water is displayed by the polarization of the molecules $\mathrm{H}-\mathrm{O}-\mathrm{H} \pm$, which changes the $\mathrm{pH}$ and the electrostatic potential $Đ U=0.04 \mathrm{mV}$. The process of de-excitation occurs via the emission of photons in the infrared range [28-30]. 
Citation: Udristioiu A, Comisel S, Popescu C, Cojocaru M (2012) Relation between LDH and Mg as Factors of Interest in the Monitoring and Prognoses of Cancer. J Bioanal Biomed 4: 001-005. doi:10.4172/1948-593X.1000055

Normally, cells in the body communicate via intra-cytoplasmic channels and maintain the energetic potential across cell membranes, which is 1-2.5 $\mu \mathrm{mol}$ of ATP in the form of ATP-ADP/ATP-ADPIMP. These normal energetic values occur during normal cell division. If the intra-cellular and extra-cellular levels of $\mathrm{Mg}^{2+}$ are high, the extra-cellular charges of the cells will not be uniformly distributed. This change in distribution induces a high net positive charge for the cell and induces a loss of contact inhibition via the electromagnetic induction of oscillation. Thereafter, malignant cells become invasive and metastasize [31-34].

\section{Conclusions}

In the current study, we showed that high serum levels of $\mathrm{Mg}$ and $\mathrm{LDH}$ were detected in patients with newly diagnosed or established malignant diseases (lung cancer, neoplasm of the bladder, LLC and chronic monocytic leukemia). Normal levels of $\mathrm{Mg}$ with moderately increased LDH levels were observed in all patients who had cancer that was in the regression phase following good responses to a specific cancer therapy. Low levels of Mg with high levels of serum LDH were observed in all patients with poor prognosis and metastases.

The total serum level of $\mathrm{LDH}$, which is released by cytolytic cells during the progression of malignant diseases and the serum $\mathrm{Mg}$ level can be used as markers for monitoring treatment responses in patients with neoplasm with or without metastasis.

\section{Acknowledgments}

Author contributions: All authors confirmed they have contributed to the intellectual content of this paper and have met the following 3 requirements: (a) significant contributions to the conception and design, acquisition of data, or analysis and interpretation of data; (b) drafting or revising the article for intellectual content; and (c) final approval of the published article.

\section{References}

1. Walter F, Boron P (2005) Medical Physiology: A Cellular and Molecular Mg Approach. Elsevier/Saunders, USA.

2. Popescu MP (2011) Cellular magnesium homeostasis (Review). Arch Biochem Biophys 5: 10 .

3. Stefano A, Roinel N, Rouffignac C, Wittner M (1993) Transepithelial $\mathrm{Ca}^{2+}$ and $\mathrm{Mg}^{2+}$ transport in the cortical thick ascending limb of Henle's loop of the mouse is a voltage-dependent process. Ren Physiol Biochem 4: 157-166.

4. Black CB, Cowan JA (1995) Magnesium-dependent enzymes in nucleic acid biochemistry. The Biological Chemistry of Magnesium 11: 735-739.

5. Dai Q, Motley SS, Smith JA Jr, Concepcion R, Barocas D, et al. (2011) Blood magnesium and the interaction with calcium, on the risk of high-grade prostate cancer. PLoS ONE 6: e18237.

6. Song Y, Manson JE, Buring JE, Liu S (2004) Dietary magnesium intake in relation to plasma insulin levels and risk of type 2 diabetes in women. Diabetes Care 27: 59-65.

7. Skinner HG, Schwartz GG (2009) A prospective study of total and ionized serum calcium and fatal prostate cancer. Cancer Epidemiol Biomarkers Prev 18: $575-578$

8. Brown EM, MacLeod RJ (2001) Extracellular calcium sensing and extracellular calcium signaling. Physiol Rev 81: 239-297.

9. Wolf FI, Maier JA, Nasulewicz A, Feillet-Coudray C, Simonacci M, et al. (2006) Magnesium and neoplasia: From carcinogenesis to tumor growth and progression or treatment. J Biol Chem 281: 29525-29532.

10. Castiglioni S, Maier JAM (2011) Magnesium and cancer: a dangerous liason Magnesium Research 24: 92-100

11. Udristioiu A (2002) Bioenergetics of normal and malign cells. Edit Academic Brancusi Targu Jiu 45-55: 136-240.
12. Spagnoli D, Jeremy P, Parker A, Parker S (2011) The structure and dynamics of hydrated and hydroxylated magnesium oxide nanoparticles. Langmuir 5 : 1821-1829.

13. Longo DL, Fauci AS, Kasper DL, Hauser SL, Jameson JL, et al. (2008) Harison`s Principle of Internal Medicine. (1 $17^{\text {th }}$ edn), Harrison's Online, London Ed, UK.

14. Le A, Cooper CR, Gouw AM, Dinavahi R (2010) What is known about the connection of LDH mutations and its serum level. Natl Acad Sci 107: 2037 2042.

15. Kehres DG, Maguire ME (2002) Structure, properties and regulation of magnesium transport proteins. Biometals 3: 261-270.

16. Dalmas O (2007) Magnesium selective ion channels. Biophys J 93: 3729-3730

17. Montell C (2003) $\mathrm{Mg}^{2+}$ Homeostasis: The $\mathrm{Mg}^{2+}$ inefficient TRPM Channel Enzymes. Current Biology 20: 799-801.

18. Runnels LW, Yue L, Clapham DE (2002) The TRPM7 channel is inactivated by PIP2 hydrolysis. Nat Cell Biol 5: 329-336.

19. Monteilh-Zoller MK, Hermosura MC, Nadler MJ, Scharenberg AM, Penner R, et al. (2003) TRPM7 provides an ion channel mechanism for cellular entry of trace metal ions. J Gen Physiol 121: 49-60.

20. Chubanov V, Waldegger S, Schnitzler M, Vitzthum H, Sassen MC, et al. (2004) Disruption of TRPM6/TRPM7 complex formation by a mutation in the TRPM6 gene causes hypomagnesemia with secondary hypocalcemia. PNAS 9: 2894 2899.

21. Voets T, Nilius B, Hoefs S, van der Kemp AW, Droogmans G, et al. (2004) TRPM6 forms the $\mathrm{Mg}^{2+}$ influx channel involved in intestinal and renal $\mathrm{Mg}^{2+}$ absorption. J Biol Chem 279: 19-25.

22. Runnels LW, Yue L, Clapham DE (2001) TRP-PLIK, a bifunctional protein, with kinase and ion channel activities. Science 291: 1043-1047.

23. Hartmann C, Meyer J, Balss J, Capper D, Mueller W, et al. (2009) Type and frequency of IDH1 and IDH2 mutations are related to astrocytic and oligodendroglial differentiation and age: a study of 1,010 diffuse gliomas. Acta Neuropathol 118: 469-474.

24. Langemeijer SM, Kuiper RP, Berends M, Knops R, Aslanyan MG, et al. (2009) Acquired mutations in TET2 are common in myelodysplastic syndromes. $\mathrm{Nat}$ Genet 41: 838-842.

25. Wagner K, Damm F, Göhring G, Görlich K, Heuser M, et al. (2010) Impact of IDH1 R132 mutations and an IDH1 single nucleotide polymorphism in cytogenetically normal acute myeloid leukemia: SNP rs11554137 is an adverse prognostic factor. J Clin Oncol 28: 2356-2364.

26. Potier L, Urbina P (1992) Single electron pump based on changing effect. Europhys Lett 17: 154-244.

27. Okorokov LA, Lichko LP, Kadomtseva VM, Kholodenko VP, Titovsky VT, et al. (1997) Energy-dependent transport of manganese into yeast cells and distribution of accumulated ions. Eur J Biochem 75: 373-377.

28. Roland K. H, Bindereif A, Schön A (2009) The Lewis acidity of Mg2+ (pKa 11.4), Handbook of RNA Biochemistry. Student Edition, Science, London, UK.

29. Kurkdjian A, Guern J (1989) Intracellular pH measurement and importance in cell activity. Annu Rev Plant Physiol Plant Mol Biol 40: 271-303.

30. Chien MM, Zahradka CE, Newel MC, Fred JW (1999) Fas induced in B cells apoptosis require an increase in free cytosolic magnesium as in early even $1 \mathrm{t}$ J Biol Chem 274: 7059-7066.

31. Milionis HJ, Bourantas CL, Siamopoulos CK, Elisaf MS (1999) Acid bases and electrolytes abnormalities in Acute Leukemia. Am J Hematol 62: 201-207.

32. Seyfried TN; Shelton LM (2010) Cancer as a Metabolic Disease. Nutr Metab $7: 7$.

33. Nasulewicz A, Wietrzyk J, Wolf FI, Dzimira S, Madej J, et al. (2004) Magnesium deficiency inhibits primary tumor growth but favors metastasis in mice. Biochim Biophys Acta 1739: 26-32.

34. Hebert SC, Brown EM, Harris HW (1997) Role of the Ca (2+)-sensing receptor in divalent mineral ion homeostasis. J Exp Biol 200: 295-302. 